EVOLUTION OF THE GAS INDUSTRY 


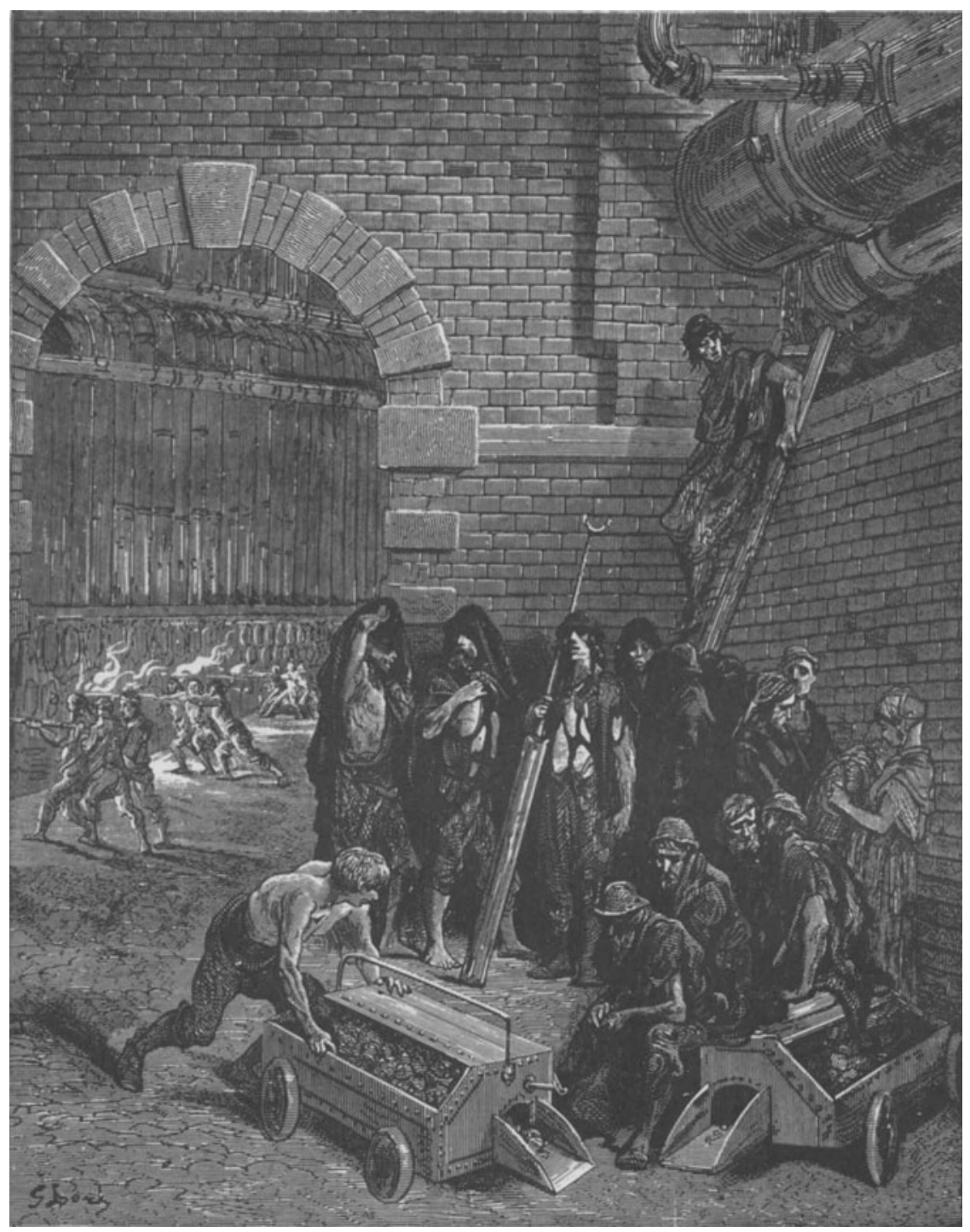

Lambeth Gas Works, London, 1872 (wood engraving by Gustave Doré) 


\section{EVOLUTION OF \\ THE GAS INDUSTRY}

Malcolm W. H. Peebles

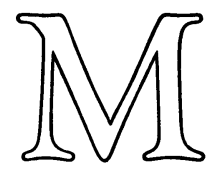


(C) Malcolm W. H. Peebles 1980

Softcover reprint of the hardcover 1st edition 1980

All rights reserved. No part of this publication may be reproduced or transmitted, in any form or by any means, without permission.

First published 1980 by

THE MACMILLAN PRESS LTD

London and Basingstoke

Associated companies in Delhi Dublin

Hong Kong Johannesburg Lagos Melbourne

New York Singapore and Tokyo

British Library Cataloguing in Publication Data

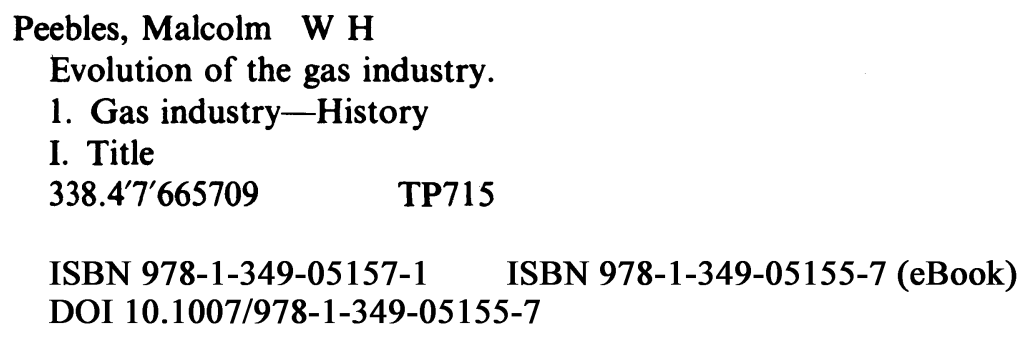

This book is sold subject to the standard conditions of the Net Book Agreement 


\section{Contents}

List of Tables

ix

Preface

Acknowledgements

1: THE HISTORICAL ORIGINS OF THE GAS INDUSTRY 5

Ancient times $\quad 5$

Gas gets its name $\quad 7$

The discovery of coal gas $\quad 7$

$\begin{array}{ll}\text { Early pioneers } & 8\end{array}$

The first commercial enterprises $\quad 9$

The incandescent mantle and new applications introduced 11

$\begin{array}{ll}\text { Improvements in manufacturing processes } & 13\end{array}$

$\begin{array}{ll}\text { Pipes, metering and storage } & 15\end{array}$

$\begin{array}{ll}\text { The pattern of development post-1900 } & 17\end{array}$

2: THE UNITED KINGDOM 21

$\begin{array}{ll}\text { The birth of the gas industry } & 21\end{array}$

$\begin{array}{ll}\text { Expansion and competition } & 23\end{array}$

$\begin{array}{ll}\text { The First World War } & 23\end{array}$

$\begin{array}{ll}\text { Between the wars } & 24\end{array}$

The Second World War $\quad 24$

Committee of Enquiry $\quad 26$

$\begin{array}{ll}\text { Nationalisation } & 26\end{array}$ 
Modernisation $\quad 27$

$\begin{array}{ll}\text { New processes } & 27\end{array}$

Liquefied natural gas $\quad 28$

$\begin{array}{ll}\text { North Sea gas } & 30\end{array}$

Contractual terms for North Sea gas 31

$\begin{array}{ll}\text { Conversion } & 33\end{array}$

British Gas Corporation $\quad 39$

Progress achieved between 1967 and $1977 \quad 39$

Financial aspects 41

The contribution from the private sector and other bodies 42

$\begin{array}{ll}\text { Future supply prospects } & 43\end{array}$

Demand considerations $\quad 46$

Recent legislation $\quad 48$

3: THE UNITED STATES 51

Historical background 51

'The heavy charge of the light brigade' 53

The wastage of natural gas $\quad 54$

The decline of manufactured gas $\quad 55$

The development of long-distance pipeline systems 55

Competition and its effect on gas usage $\quad 57$

Pressures build up for legislative controls $\quad 59$

The Natural Gas Act $\quad 59$

The Phillips decision $\quad 60$

The area approach to price regulation $\quad 61$

The national approach to price regulation 61

Some pros and cons of regulation $\quad 62$

The structure of the American gas industry 64

The domestic or residential market $\quad 66$

The commercial market $\quad 70$

The industrial market $\quad 71$

Interruptible sales $\quad 74$

The 1973 shocks 75

The Emergency Gas Act of $1977 \quad 78$

The demise of the FPC 78

The National Energy Plan $\quad 80$

The Natural Gas Policy Act $\quad 81$

Exports and imports $\quad 84$

Natural gas liquids $\quad 85$

Some concluding thoughts $\quad 88$

4: JAPAN 91

$\begin{array}{ll}\text { The early days } & 91\end{array}$ 
The post-Russo-Japanese War period $\quad 92$

Gas-making processes $\quad 95$

The gas industry goes into decline 95

The post-First World War era 96

Legislation $\quad 96$

The business grows $\quad 97$

Second World War $\quad 97$

The immediate post-war years $\quad 98$

New legislation $\quad 98$

New feedstocks and natural gas $\quad 99$

Customer growth and consumption trends $\quad 100$

LNG for power generation $\quad 104$

Types of gas distributed 107

$\begin{array}{ll}\text { Number of gas undertakings } & 107\end{array}$

Conversion 108

The introduction of LNG 109

The role and future scope for LNG 110

Summary 111

5: THE NETHERLANDS 113

Early developments 113

The immediate post-war period $\quad 115$

The Mining Act of $1810 \quad 119$

The foundation of NAM 120

The search for hydrocarbons $\quad 120$

The introduction of natural gas 121

The discovery of Groningen gas field 122

The nature of the Groningen field 123

Arrangements for the exploitation of Groningen gas 125

$\begin{array}{ll}\text { The agreement for co-operation } & 128\end{array}$

Ministerial discretions 128

$\begin{array}{ll}\text { Construction of the pipeline system } & 129\end{array}$

Conversion 131

The reorganisation of the public distribution market 132

The development of the domestic market 132

The industrial market $\quad 134$

$\begin{array}{ll}\text { Pricing policies } & 136\end{array}$

Exports 138

Liquefied natural gas 143

General conclusions on progress to date 144

6: THE UNION OF SOVIET SOCIALIST REPUBLICS 147

General considerations 
$\begin{array}{ll}\text { Pre-revolutionary days } & 148\end{array}$

Soviet plans and developments between 1928 and $1945 \quad 149$

$\begin{array}{lr}\text { The Fourth and Fifth Soviet Plans } & 150\end{array}$

$\begin{array}{ll}\text { The emphasis changes to natural gas } & 153\end{array}$

$\begin{array}{ll}\text { The development of natural gas reserves } & 155\end{array}$

$\begin{array}{ll}\text { The super-giants and future expectations } & 157\end{array}$

Expectations and achievements in gas production 1966-78 159

$\begin{array}{ll}\text { Transportation } & 161\end{array}$

$\begin{array}{lr}\text { Market sectors } & 164\end{array}$

$\begin{array}{ll}\text { Natural gas imports } & 166\end{array}$

Exports of Soviet gas to East Europe 169

$\begin{array}{ll}\text { Exports of Soviet gas to West Europe } & 172\end{array}$

$\begin{array}{ll}\text { The Orenburg project } & 175\end{array}$

$\begin{array}{lr}\text { Liquefied natural gas export prospects } & 179\end{array}$

$\begin{array}{lr}\text { The import/export balance } & 180\end{array}$

$\begin{array}{ll}\text { Summing-up } & 181\end{array}$

7: LIQUEFIED NATURAL GAS 185

$\begin{array}{lr}\text { Basic considerations } & 185\end{array}$

$\begin{array}{ll}\text { Early research and experimentation } & 186\end{array}$

$\begin{array}{ll}\text { The birth of the LNG industry } & 187\end{array}$

Cleveland-the world's first LNG peak-shaving plant 187

$\begin{array}{ll}\text { The Moscow plant } & 188\end{array}$

The Chicago Union Stock Yards project 189

$\begin{array}{ll}\text { Ocean transport of LNG } & 190\end{array}$

$\begin{array}{ll}\text { The Algeria-UK/France projects } & 190\end{array}$

$\begin{array}{ll}\text { LNG peak-shaving makes a comeback } & 194\end{array}$

$\begin{array}{ll}\text { The development of international LNG projects } & 195\end{array}$

$\begin{array}{ll}\text { The Brunei-Japan LNG project } & 195\end{array}$

Other operational base-load projects $\quad 200$

$\begin{array}{ll}\text { Prices and pricing } & 203\end{array}$

$\begin{array}{ll}\text { LNG systems } & 204\end{array}$

$\begin{array}{ll}\text { Production } & 205\end{array}$

$\begin{array}{ll}\text { Liquefaction } & 205\end{array}$

$\begin{array}{lr}\text { Shipping } & 206\end{array}$

$\begin{array}{ll}\text { Terminals } & 209\end{array}$

$\begin{array}{ll}\text { What of the future? } & 209\end{array}$

Glossary of Some Common Gas Industry Terms 211

Symbols, Abbreviations and Natural Gas Equivalents $\quad 217$

$\begin{array}{lr}\text { Selected References } & 223\end{array}$

$\begin{array}{ll}\text { Index } & 227\end{array}$ 


\section{List of Tables}

CHAPTER 2: THE UNITED KINGDOM 21

2.1 Progress of customer conversion to natural gas 37

2.2 Average producer and retail prices 38

2.3 Raw materials used for gas manufacture/supply 40

2.4 Types and capacities of gas making plant 40

2.5 British Gas: statistical data for April 1977/March 1978

CHAPTER 3: THE UNITED STATES 51

3.1 Average wellhead prices for new gas, interstate sales only: 1954-59 62

3.2 Transmission system and installed compressors: 1950-77 65

3.3 Domestic customers and consumption rates: 1945-77 68

3.4 Average annual consumption per type of appliance/end use

3.5 Commercial customers, sales, consumption and revenue: 1945-77 71

3.6 Industrial customers, sales, consumption and revenue: 1945-77 72

3.7 Saudi Arabian Light: OPEC marker crude oil prices 76

3.8 United States total natural gas supply and production 1946-77 77

3.9 Assessed maximum lawful prices: January $1979 \quad 82$

3.10 NGL production in USA: $1972-76$

CHAPTER 4: JAPAN 91

4.1 Number of gas connections/customers: 1968 and $1977 \quad 100$

4.2 Sales by gas companies: 1968 and 1977 
4.3 Average annual consumption: 1968 and $1977 \quad 101$

4.4 Gases available for distribution: 1968 and $1977 \quad 108$

CHAPTER 5: THE NETHERLANDS 113

$\begin{array}{lll}5.1 & \text { Natural gas compositions } & 124\end{array}$

5.2 Sales of natural gas by Gasunie within the Netherlands 136

5.3 Exports of Dutch gas: 1963-70 139

$\begin{array}{ll}5.4 \text { Exports of Dutch gas: } 1971-78 & 140\end{array}$

CHAPTER 6: THE UNION OF SOVIET SOCIALIST REPUBLICS

6.1 Soviet gas production and utilisation: 1928-58 152

$\begin{array}{lll}\text { 6.2 The target for gas utilisation in } 1965 & 154\end{array}$

6.3 Apparent percentage consumption of primary energy 155

6.4 Natural gas reserves $\left(A+B+C_{1}\right)$ by main region 157

$\begin{array}{ll}\text { 6.5 Major Soviet gas fields } & 158\end{array}$

6.6 Natural gas production: actuals versus plans: 1966-80 160

6.7 Development of the Soviet Union's gas pipeline system: 1961-77 162

6.8 Domestic market: customers and gas supplies for selected years $\quad 165$

6.9 Utilisation of natural gas by main market sector: 1961-77 166

6.10 USSR imports of natural gas: 1967-77 168

6.11 Exports of Soviet natural gas to East Europe: 1967-77 171

6.12 Exports of Soviet natural gas to West Europe: 1968-77 175

6.13 Summary of exports/imports of natural gas: 1967-77 180

6.14 Average apparent import/export border prices for natural gas 181

CHAPTER 7: LIQUEFIED NATURAL GAS 185

7.1 International trade in LNG by 1980202

SYMBOLS, ABBREVIATIONS AND NATURALGAS EQUIVALENTS $\quad 217$

$\begin{array}{ll}\text { Natural gas: cubic metre equivalents } & 218\end{array}$

Natural gas: cubic foot equivalents $\quad 219$

LNG: volumetric equivalents $\quad 220$

$\begin{array}{ll}\text { Oil and coal equivalents } & 221\end{array}$ 


\section{Preface}

In the beginning man relied solely upon muscle power, that of his own and no doubt that of animals as well. Then, at some unknown point in time, probably many thousands of years ago, prehistoric man discovered how to make fire and to burn wood and other primitive fuels such as dried peat and animal dung to keep him warm and to cook his food. The first use of coal is not recorded, but no doubt this also dates back several thousand years-certainly it was in relatively common use by Roman times. However, it was not until the Industrial Revolution that energy began to be used by man on a massive and widespread scale.

The Industrial Revolution was fuelled principally by coal. Thereafter coal remained king of the energy scene until shortly after the Second World War when it was displaced by oil, which then became the world's largest individual source of primary energy supply. Today oil supplies about 44 per cent of the world's energy requirements, or 55 per cent if the communist countrieswhich still rely heavily on coal-are excluded.

Natural gas, with a few exceptions, notably in the United States, is a relative newcomer to the energy scene compared with oil and in its turn has largely displaced manufactured gas (by definition a secondary form of energy) during the last two to three decades. One illustration of the rapid growth that natural gas has achieved over this period is Western Europe. In 1965 the contribution made by natural gas to total primary energy consumption was barely 2 per cent, but by 1977 this had expanded to over 17 per cent.

This remarkable increase in the use of natural gas in Europe, mirrored to a lesser or greater extent in a number of countries elsewhere in the world, has been realised primarily at the expense of coal. For example, in Western Europe coal's share of primary energy consumption for the same two years of 1965 and 1977 declined from 47 per cent to 24 per cent, in spite of the overall increase in energy consumption over this period. This was not just a decline in 
coal's percentage contribution, but a substantial reduction as well in the absolute volumes of coal consumed. Moreover, apart from the displacement of coal per se, natural gas in replacing manufactured gas made largely from coal represented the loss of a further important outlet for coal as a gas-making feedstock.

Although coal was probably the principal sufferer from the inroads of natural gas, the expansion in the use of natural gas has also been partly at the expense of the growth rates that oil products, in particular fuel oil and gas oil (and also electricity), might otherwise have enjoyed but for the introduction of natural gas. Admittedly, various factors have favoured natural gas in many countries, including its low price relative to the prices of competing fuels, and its cleanliness and hence desirability as a fuel in a world growing ever more conscious of its environment. Furthermore, it should not be overlooked that indigenous natural gas, where available, was often preferred and received some form of encouragement over imported oil for political, security of supply, and balance of payment reasons. This was not true everywhere, but it was certainly the case in a number of countries.

The size of the world's proven natural gas reserves, coupled with high expectations for substantial new discoveries, indicate that supply availability could continue growing well into the next century. On the other hand oil supplies, based on existing reserves and future expectations, could well plateau out at an earlier date. Newer forms of energy such as nuclear power, solar, wind or tidal energy, have either yet to make a significant contribution, or pose considerable practical problems for which solutions will not be found overnight.

All this points to a bright future for a natural-gas-based gas industry. At the same time a return to a gas industry relying, as it did until fairly recently, on complicated and expensive manufacturing processes for converting solid and liquid fuels to combustible gases seems remote, other than the use of high calorific value manufactured gas as a supplement, where necessary and appropriate, to natural gas supplies.

The balance of probability is, therefore, that the world's gas industry will for many years to come rely increasingly or exclusively on natural gas as its prime source of supply. This book attempts to record, before memories fade and the facts become too obscured or lost with the passage of time, how the gas industry has evolved over the years since its creation in the early nineteenth century. Attention has been concentrated on certain selected countries. In each selected case the gas industry has developed in a unique way conditioned by local circumstances; no one country or market has followed a pattern of development which may be regarded as being typical for the industry as a whole. Obviously, there are other countries not described in this book where the pattern of development has not differed too dramatically from one or other of the countries reviewed, but even so there are usually subtle differences of consequence which the serious student would be well advised to 
investigate in depth before arriving at any premature conclusions.

Each and every gas market has its own peculiarities of supply, government involvement, or lack of involvement as the case may be, pricing, and competition with other energy forms, exacerbated by the social and environmental conditions applicable therein. The gas business may be becoming more international in character, but it still falls a long way short of some of the more general influences that govern the conduct of the international oil and coal businesses which have received so much publicity and informed opinion in recent years.

Little aattempt has been made to look too far into the future as we are concerned here primarily with what has happened in the past. I hope this book will serve as a factual base from which some readers may wish to start considering how the future conduct and prosperity of the business may evolve.

Claygate, Surrey

M.W.H.P 


\title{
Acknowledgements
}

I wish to express my gratitude to many friends and colleagues in the gas industry around the world whose interest, encouragement and assistance has helped to make this book possible. I am particularly indebted to Lou Brocker, Tony Budd, Charles Case, Yuri Domrachev, Drew Hamilton, Minoru Ikushima, Alan Levine, Brian McLellan, Jeremy Russell, Eric Short, Don Stephenson, and Jan Visser, either for their opinions and constructive comments, and/or for the trouble they have taken to seek out suitable reference material and illustrations for me. My special thanks are also due to Anne Luget for her excellent and patient typing of my manuscript.

In addition, a number of national and international organisations have kindly made available to me various books, reports, illustrations, and the like, and, where appropriate, have granted me permission to use certain copyright material. Their ready co-operation in these matters has been of considerable assistance; in particular my thanks to:

\author{
Atlanta Gas Light Company \\ British Gas Corporation \\ Brooklyn Union Gas Company \\ Conch Methane Services Limited \\ Gas Shiryo-kan \\ Gotaas-Larsen Inc. \\ Japan Gas Association \\ N.V. Nederlandse Gasunie \\ Oil and Gas Journal \\ Osaka Gas Company Limited \\ Petroleum Economist \\ Ruhrgas Aktiengesellschaft \\ Shell International Gas Limited
}


Southern Natural Gas Company

Sojuzgazexport

Tokyo Gas Company Limited

Finally, I wish to make it clear that the responsibility for any errors, significant omissions, expressions of opinion, interpretations of facts and statistics, rests entirely with me. This book has been a personal project and as such does not purport to represent the views of any particular organisation. 